\title{
BAMBU COMO MATÉRIA PRIMA PARA DESENVOLVIMENTO DE MOBILÁRIO INFANTIL
}

\section{Thalita Leal Dutra, Bacharel (UFSC) Ana Veronica Pazmino, Dra. (UFSC)}

\section{INTRODUÇÃO}

A utilização de bambu no setor industrial brasileiro ainda é muito incipiente. Os fatores que estimulam sua utilização são animadores; o Brasil possui ótimas perspectivas para seu cultivo, tais como: clima adequado, disponibilidade de áreas cultiváveis, amplo mercado interno e oportunidades de exportação para mercados que buscam cada vez mais produtos naturais e, sobretudo de baixo impacto ambiental.

\section{DESENVOLVIMENTO}

O projeto foi desenvolvido para o Núcleo de Desenvolvimento Infantil - NDI, vinculado ao Centro de Ciências da Educação da Universidade Federal de Santa Catarina. Identificou-se que o mobiliário deveria ser uma

\section{Figura 1 Estante Encantada}

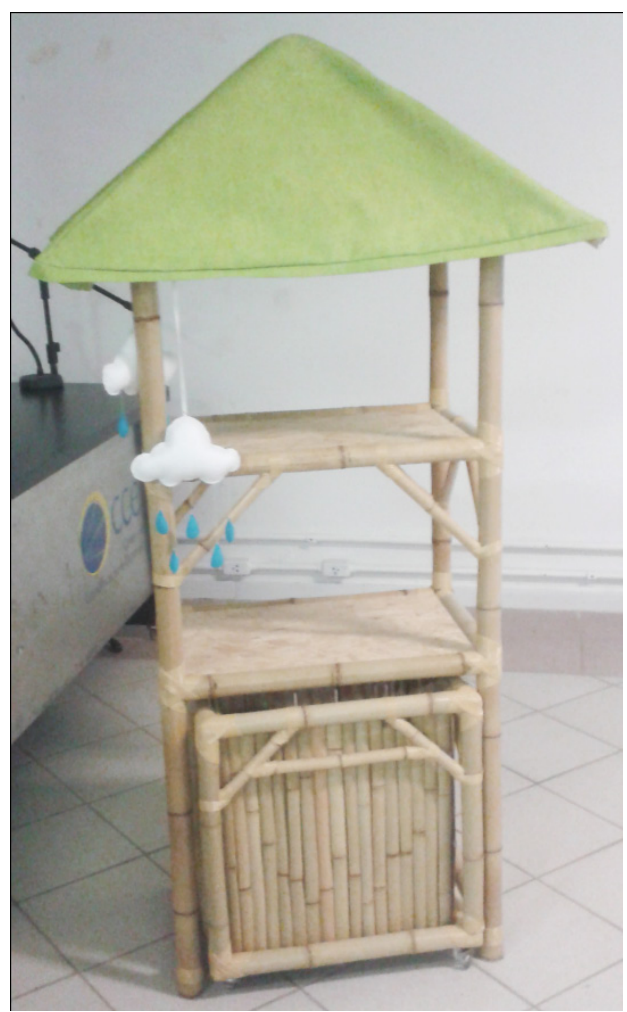

Fonte: Dutra (2015) estante para ser utilizada na biblioteca servindo para colocar os livros e realizar atividades lúdicas e divertidas com as crianças.

De acordo com os requisitos de projeto foram geradas alternativas e junto com o artesão Gilmar Telles do Bambu Arte, foi escolhida e desenvolvida uma estante intitulada Estante Encantada, ela foi projetada de acordo com os padrões antropométricos da faixa etária de três anos de idade atendendo as necessidades encontradas no NDI UFSC, e a viabilidade de construção artesanal da mesma.

A estante possui espaço para armazenar livros (4 prateleiras); brinquedos (2 baús); e um cenário central para uso das crianças e professores, também oferece elementos lúdicos que remete à contação de histórias e reforça o estilo divertido e lúdico que a estante propõe como pode ser observado na Figura 1.

O bambu utilizado é da espécie Phyllostachys aurea, com espessura de $4 \mathrm{~cm}$. Elementos como: amarras sintéticas, tábua OSB, grampos, rodízios e tecidos compõem sua fabricação.

\section{CONCLUSÃO}

O trabalho de conclusão do curso abordou o Design Sustentável a partir da pesquisa das propriedades do Bambu e sua potencialidade de uso e difusão no mercado. Além dos inúmeros benefícios que esta gramínea apresenta. O público-alvo foi identificado por meio da necessidade de abordar fatores sociais ao projeto, aliar a capacidade de uso do bambu a uma instituição de ensino e assim provocar mudanças positivas em seu contexto social; além de disseminar o conhecimento sobre esta matéria-prima e expandir projetos que a envolva.

\section{REFERÊNCIA}

DUTRA, Thalita. Bambu como Matéria Prima para Desenvolvimento de Mobiliário Infantil. Projeto de Conclusão do curso de design da Universidade Federal de Santa Catarina. Florianópolis, 2015.

GERN, Gabriel. A Utilização do Bambu como Material Ecológico no desenvolvimento de Mobiliários. 
Monografia de Graduação em Design. Universidade da Região de Joinville, 2008.

MANHÃES, Adriana. Caracterização da Cadeia Produtiva do Bambu no Brasil: abordagem Preliminar. Universidade Rural do Rio de Janeiro, 2008. Disponível em: <http://bambusc.org.br/wp-content/uploads/2009/05/ caracterizacao_cadeira_produtiva_adriana_pellegrini_ manhaes.pdf $>$. Acesso em: 22 de Abril de 2015.

PAZMINO, Ana Veronica. Como Se cria: $\mathbf{4 0}$ métodos para o design de produtos. São Paulo: Editora Blucher, 2015. 